The Common Agricultural Policy of the European Union the present and the future

EU Member States

point of view 



\section{INSTITUTE OF AGRICULTURAL AND FOOD ECONOMICS NATIONAL RESEARCH INSTITUTE}

\section{The Common Agricultural Policy of the European Union - the present and the future}

\section{EU Member States point of view}

Editors:

dr Marek Wigier

prof. dr hab. Andrzej Kowalski

Proceedings of the International Scientific Conference

"The Common Agricultural Policy of the European Union - the present and the future" Multi-Annual Programme 2015-2019

"The Polish and the EU agricultures 2020+. Challenges, chances, threats, proposals" 5-7 December 2017 Stare Jabłonki, Poland

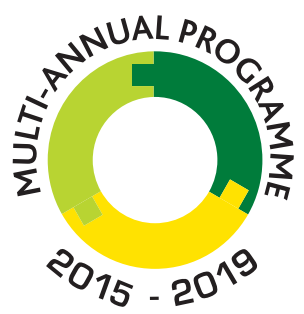

THE POLISH AND THE EU AGRICULTURES 2020+ CHALLENGES, CHANCES, THREATS, PROPOSALS

Warsaw 2018 
This monograph was prepared under the Multi-Annual Programme 2015-2019

"The Polish and the EU agricultures 2020+. Challenges, chances, threats, proposals".

The publication is a collection of selected papers delivered at the 22th edition of the International Scientific Conference organized by the Institute of Agricultural and Food Economics - National Research Institute. The theme of the conference was "The Common Agricultural Policy of the European Union the present and the future. The conference was placed on 5-7 December 2017 in Stary Jabłonki in Poland. Common Agricultural Policy was and still is one of the key pillars of European integration. Published in two volumes materials refer directly to the current and future of the CAP in EU and non EU member states, the strategic objectives and principles of agricultural policy for the agri-food sector and rural areas, address the issues of equilibrium between agriculture, forestry and land use, relate to the dilemmas for the EU budget and the CAP after 2020, CAP instruments and their adjustment, transformations of the rural economy and programming of the rural and agricultural policy, as well as productivity and production efficiency and tensions between sectoral action and between different models of territorial activities.

In the Scientific Committee of the Conference was participated: Prof. Andrzej Kowalski (IAFE-NRI, Poland), Prof. Drago Cvijanonivić (University of Kragujevac, Serbia), Prof. Thomas Doucha (IAEI, Czech Republic), Noureddin Driouech, PhD (CIHEAM, Italy), Prof. Szczepan Figiel (IAFE-NRI, Poland), Prof. Masahiko Gemma (Waseda University, Japan), Prof. Wojciech Józwiak (IAFE-NRI, Poland), Prof. Jacek Kulawik (IAFE-NRI, Poland), Prof. Yuriy Oleksiyovych Lupenko (IAE, Ukraina), Prof. Věra Majerová (CULS, Prague), Prof. Dimitre Nikolov (IAE, Bulgaria), Maire Nurmet, PhD (EMÜ, Estonia), Prof. Gabriel Popescu (ASE, Romania), Norbert Potori, PhD (AKI, Hungary), Prof. Włodzimierz Rembisz (IAFE-NRI, Poland), Piotr Szajner, PhD (IAFE-NRI, Poland), Prof. Alina Sikorska (IAFE-NRI, Poland), Prof. Jonel Subić (IAE, Serbia), Prof. Samuele Trestini (UNIPD, Italy), Prof. Olga Varchenko (Bila Tserkva National Agrarian University, Ukraine), Dipl.-Ing. Klaus Wagner (AWI, Austria), Marek Wigier, PhD (IAFE-NRI, Poland), Prof. Józef St. Zegar (IAFE-NRI, Poland)

In the Organising Committee of the Conference was participated: Małgorzata Bułkowska (IAFE-NRI, Poland), Anna Hankiewicz (IAFE-NRI, Poland), Joanna Jaroszewska (IAFE-NRI, Poland), Joanna Korczak (IAFE-NRI, Poland), Krzysztof Kossakowski (IAFE-NRI, Poland), Irena Mikiewicz (IAFE-NRI, Poland), Małgorzata Mikołajczyk (IAFE-NRI, Poland), Lech Parzuchowski (IAFE-NRI, Poland), Ewa Sierakowska (IAFE-NRI, Poland), Paulina Smakosz (IAFE-NRI, Poland), Leszek Ślipski (IAFE-NRI, Poland), Marek Wigier, PhD (IAFE-NRI, Poland).

Reviewers:

Professor Dimitre Nikolov, Institute of Agricultural Economics, Sofia, Bulgaria

Professor Gabriel Popescu, The Bucharest University of Economic Studies, Bucharest, Romania

Professor Samuele Trestini, University of Padva, Italy

Proofreader

Katarzyna Mikulska

Technical editors:

Joanna Jaroszewska, Barbara Pawtowska, Ewa Sierakowska, Kamila Tomaszewska,

Barbara Walkiewicz

Translated by

Summa Linguae S.A.

Cover Project

Leszek Ślipski

ISBN 978-83-7658-743-1

DOI: $10.30858 / \mathrm{pw} / 9788376587431$

Instytut Ekonomiki Rolnictwa i Gospodarki Żywnościowej

- Państwowy Instytut Badawczy

ul. Świętokrzyska 20, 00-002 Warszawa

tel.: (22) 5054444

faks: (22) 5054636

e-mail:dw@ierigz.waw.pl

http://www.ierigz.waw.pl 


\section{Contents}

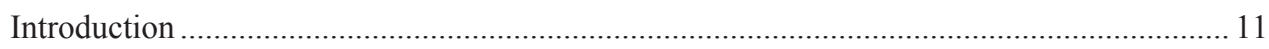

Dr Marek Wigier

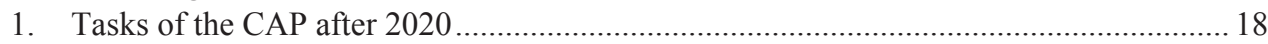

Dr hab. Julian Krzyżanowski

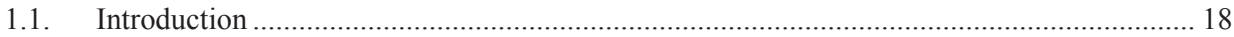

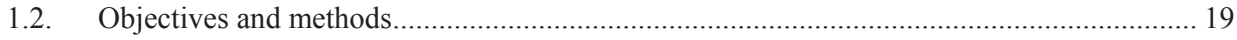

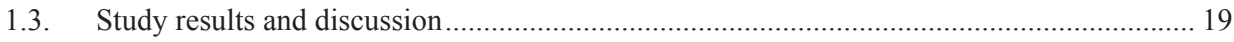

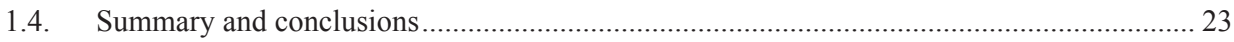

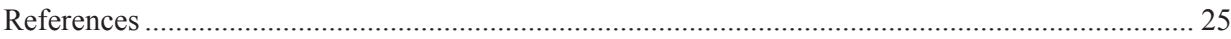

2. An assessment of the regional impacts of post-2020 CAP budgetary cuts on production

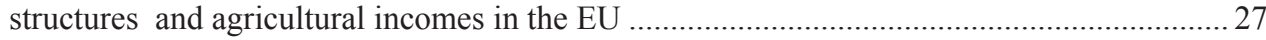

PhD Norbert Potori, PhD János Sávoly, PhD Szabolcs Biró

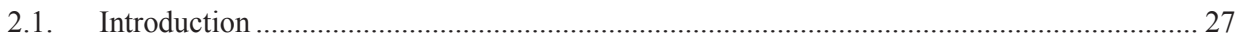

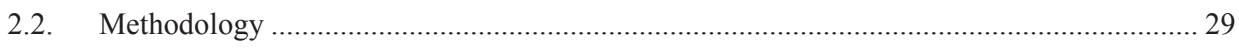

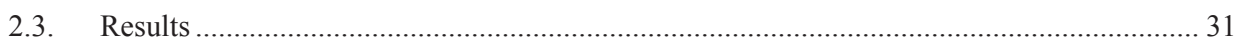

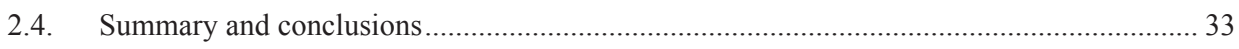

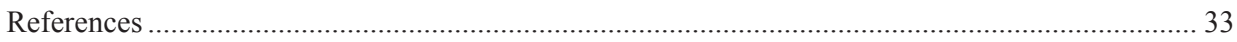

3. Is there room for financial instruments in the Common Agricultural Policy? Casus of

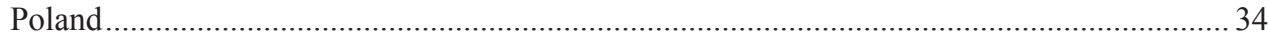

Prof. dr hab. Jacek Kulawik, PhD Barbara Wieliczko, PhD Michat Soliwoda

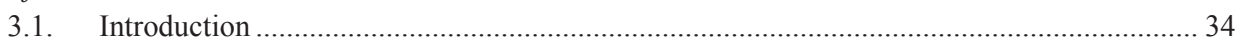

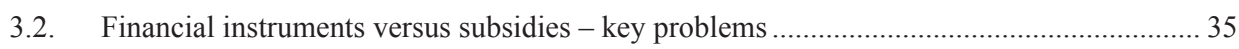

3.3. The use of financial instruments under the EU policy ......................................................... 37

3.4. Example of the use of FI in the 2014-2020 programming period ......................................... 38

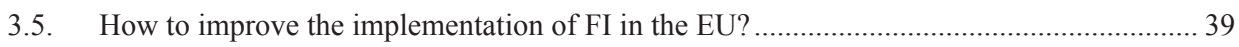

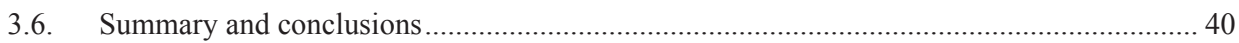

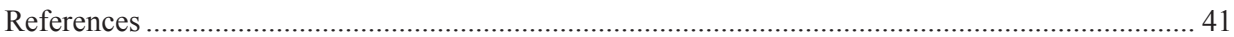

4. The past, present and future of the CAP - the Hungarian viewpoint ............................. 43

Dr Tamás Mizik

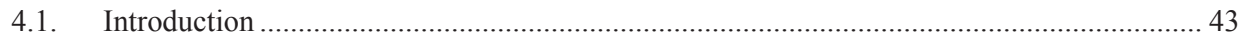

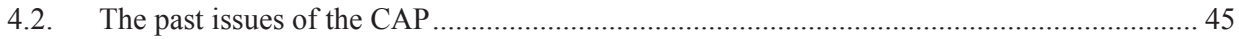

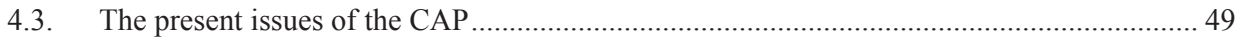

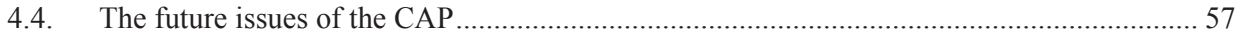

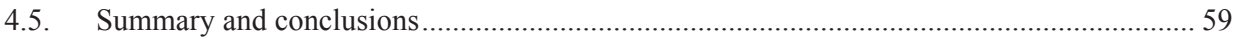

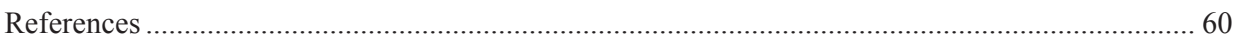


5. Going beyond the Rural Development Programme: a Master Plan for Austria's rural areas in the framework of the CAP

Dip.-Ing. Klaus Wagner

5.1. Introduction

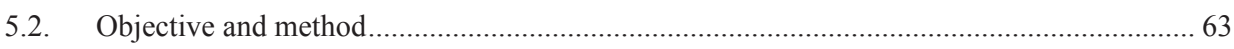

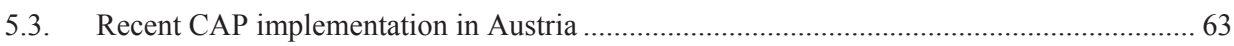

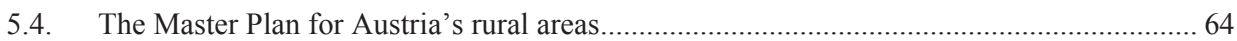

5.5. CAP in the system of the EU policy objectives and in the view of regional science

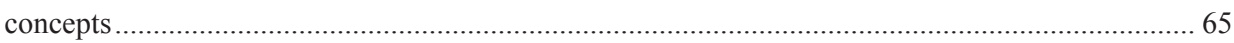

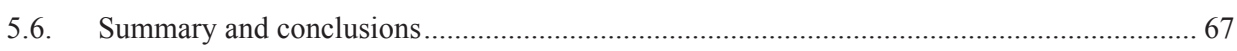

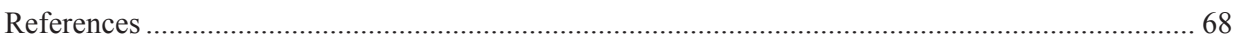

6. Possibilities to connect the Romanian agricultural research to the market requirements 69 Prof. Gabriel Popescu

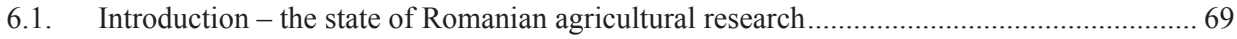

6.2. The problems faced by agricultural research since 1990 ..................................................... 71

6.3. Possible solutions for the recovery of Romanian agricultural research ................................ 76

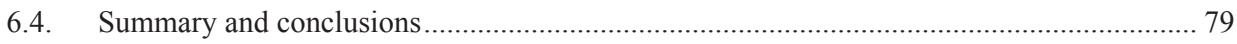

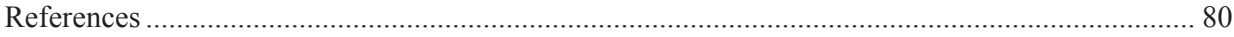

7. Price relationships of the production factors as exogenous determinants of production in agriculture.

Prof. dr hab. Włodzimierz Rembisz, PhD Adam Waszkowski

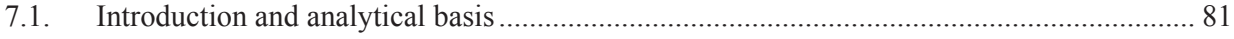

7.2. Relationships of prices of the capital, labour and land factors - hypothetical approach...... 83

7.3. Relationships of prices of the capital, labour and land factors - empirical approach .......... 84

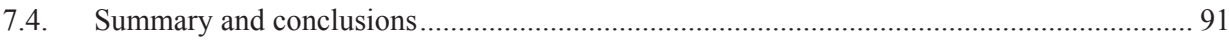

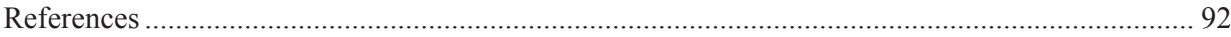

8. Effects of direct payments on agricultural development in Bulgaria ............................. 93 PhD Bozhidar Ivanov

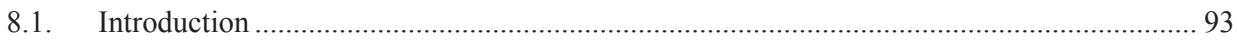

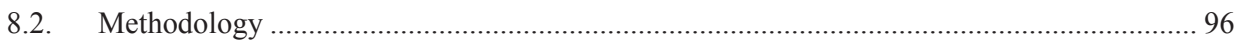

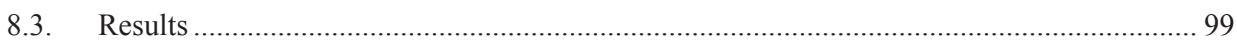

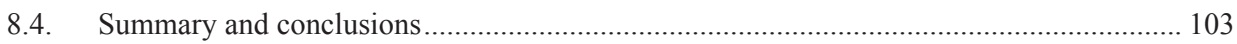

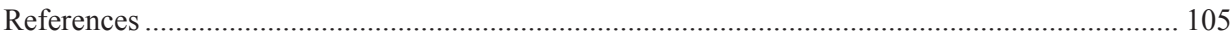

9. Re-adjusting risk management within the CAP: evidences on the implementation of the

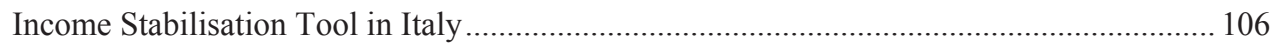
Prof. Samuele Trestini, PhD Elisa Giampietri

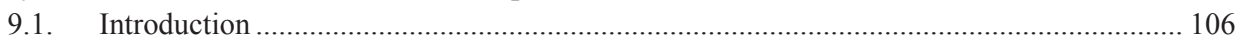

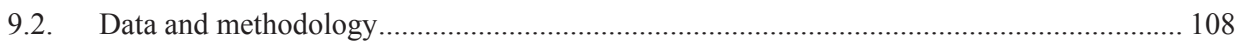




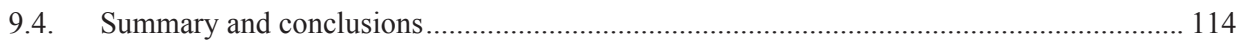

References

10. Comparison of risk management tools under the CAP of the EU, the US Farm Bill

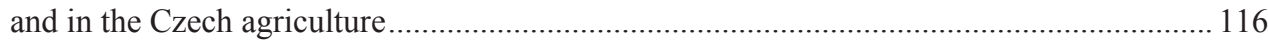
Ing. Václav Vilhelm, CSc., Ing. Sumudu Namali Gouri Boyinová, PhD Jindřich Špička

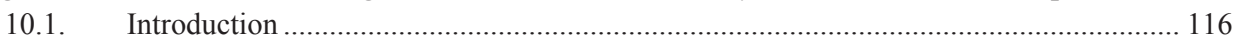

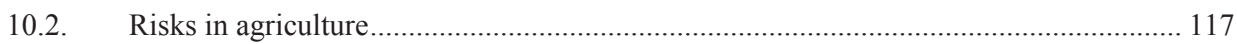

10.3. Risk management policy in the United States Farm Bill 2014 _..................................... 118

10.4. Risk management policy of the European Union's CAP ................................................ 119

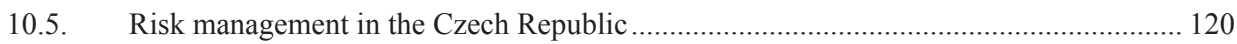

10.6. Comparative analysis of risk management policies ........................................................ 121

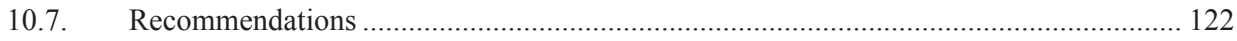

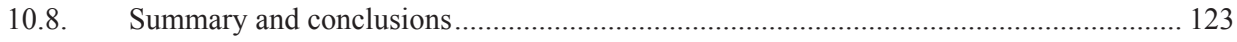

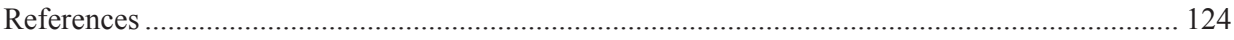

11. Factors determining the crop insurance level in Poland taking into account the level

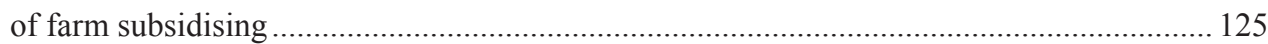

Prof. Adam Was, PhD Pawet Kobus

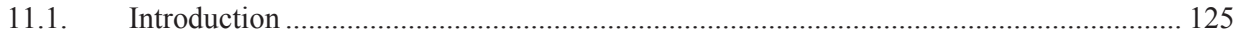

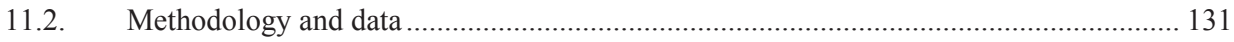

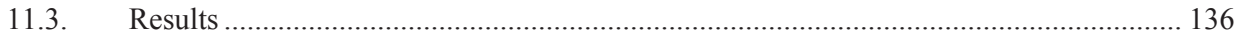

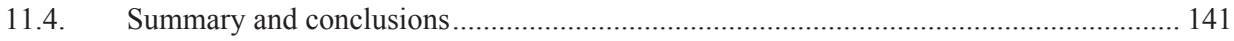

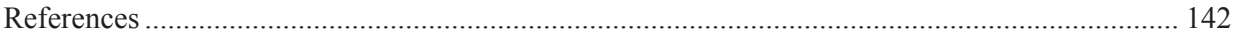

12. Farms and agricultural enterprises for development of sustainable and smart cooperatives: a multifactor approach using digital farm management ............................... 147 Prof. dr habil Adriana Mihnea, Prof. dr Dimitre Nikolov, dr Krasimir Kostenarov

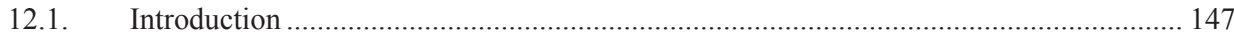

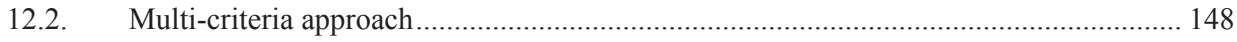

12.3. Construction of Farm Management Model ................................................................ 150

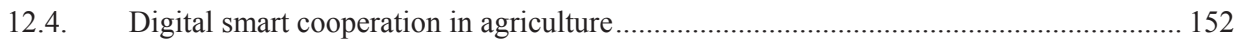

12.5. Application of the ANP Farm Management Model ....................................................... 154

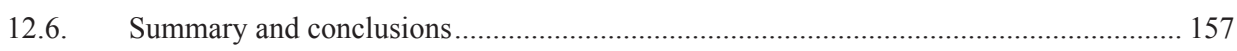

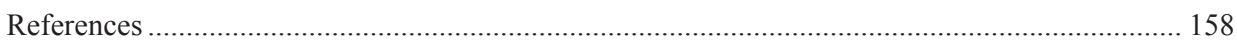

13. Brexit - potential implications for the Polish food sector .............................................. 159

Dr Katarzyna Kosior, Dr Łukasz Ambroziak

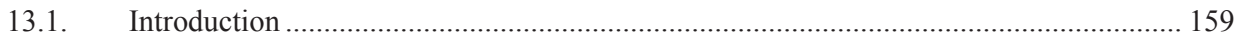

13.2. Negotiations on Brexit - what should be the model of the future relations? ..................... 161

13.3. The future of the EU finances and the CAP in the context of Brexit .............................. 163 
13.4. Impact of possible changes in the CAP budget on the net balance of Poland and transfers to the Polish agriculture.

13.5. The potential impact of Brexit on agri-food trade between Poland and the United

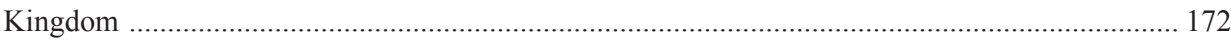

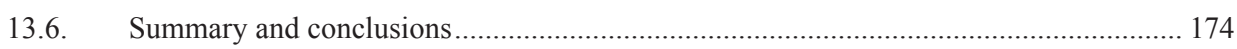

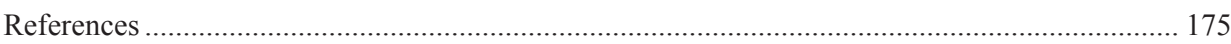

14. The Transatlantic Trade and Investment Partnership (TTIP): a threat or an opportunity for the EU-Mediterranean agriculture and agri-food sector? An exploratory survey ........... 177 Dipl.-Ing. Katja Pietrzyck, PhD Noureddin Driouech, Prof. Brigitte Petersen

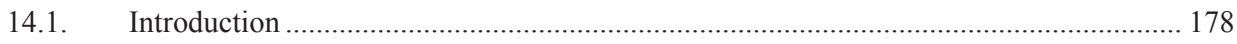

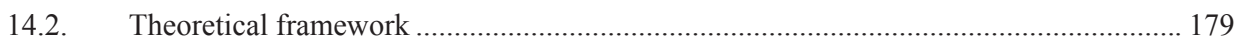

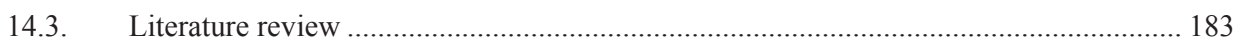

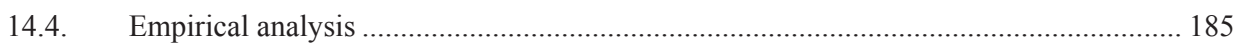

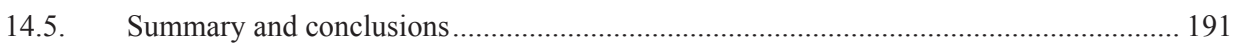

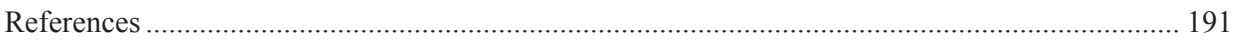

Appendix I: Overview of trade statistics regarding selected products ........................................... 195

15. The concept of short supply chains in the food economy............................................. 196

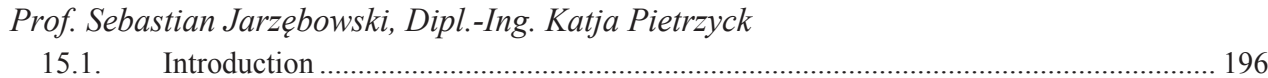

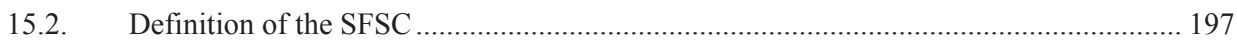

15.3. Development of short supply chains in Europe............................................................. 201

15.4. Global context of European short supply chains ........................................................... 205

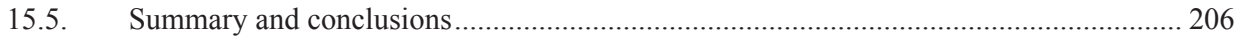

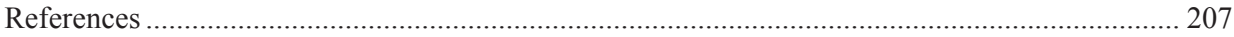

16. The CAP implementation in Wallonia - today performance and questions for the future -

A brief supplementary comment from Warmia and Mazury perspective............................. 209

PhD Philippe Burny, PhD Benon Gazinski

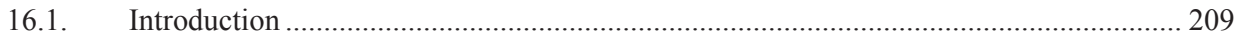

16.2. Implementation of the green payment in Wallonia in 2015 ........................................ 210

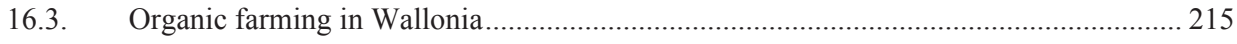

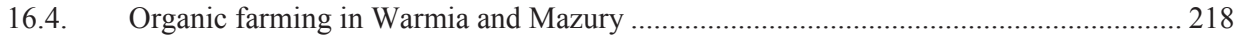

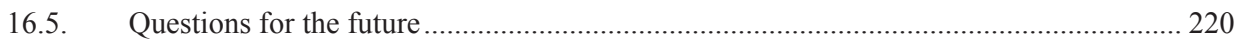

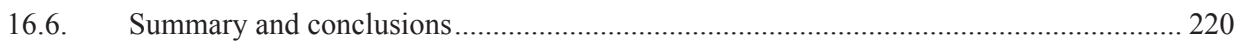

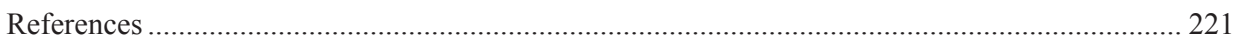

17. Afforestation of agricultural land financed from the RDP 2014-2020 ....................... 224

PhD Marek Zieliński

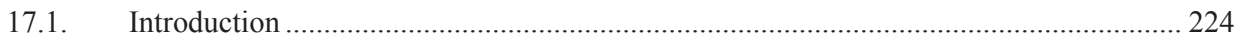

17.2. Natural farming conditions in Poland in regional terms................................................. 225 
17.3. The impact of natural farming conditions in Poland on the economic situation and the possibility of afforestation on farms

17.4. Land afforestation financed from the RDP 2014-2020 in regional terms

17.5. Importance of land afforestations financed under the RDP 2014-2020 in the EU climate policy for 2021-2030.

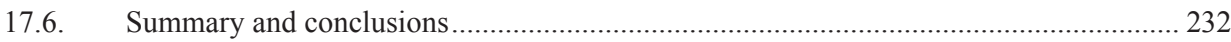

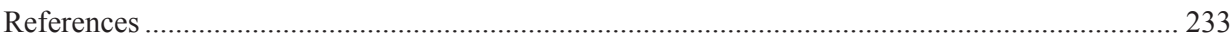

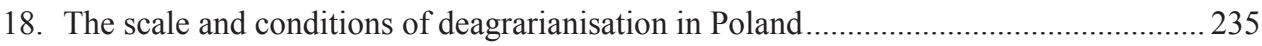

PhD Michat Dudek, PhD Bożena Karwat-Woźniak

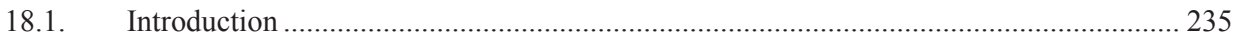

18.2. The conditions of the decrease in employment in agriculture ......................................... 236

18.3. The change in the scale of employment in agriculture in Poland and its conditions....... 238

18.4. The instruments of the Cohesion Policy and agriculture and rural development of the EU

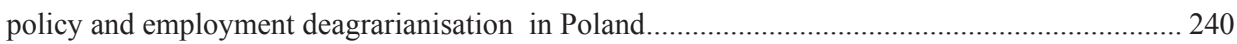

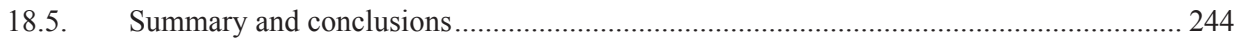

References 245

19. Socio-economic and environmental parameters and results of rural development under the CAP: the case of Bulgaria ................................................................................................ 247 Prof.dr.hab. Julia Doitchinova, Prof.dr.hab. Ivan Kanchev, Ass.Prof. Ralitsa Terziyska PhD, Ass.Prof. Kristina Todorova PhD

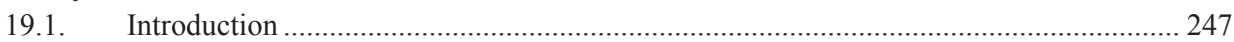

19.2. Changes in Bulgarian rural areas - socio-economic and environmental aspects................ 248

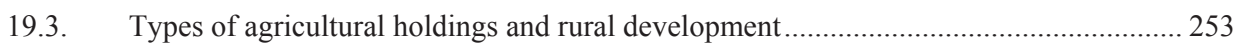

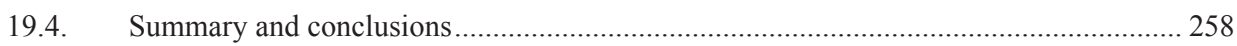

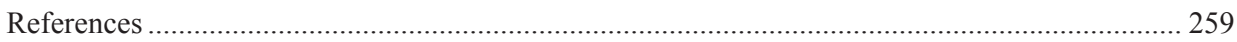

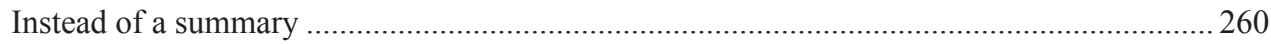

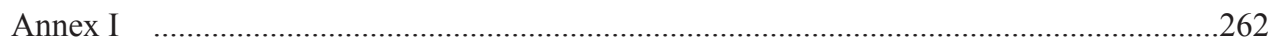




\title{
18. The scale and conditions of deagrarianisation in Poland
}

\author{
PhD Michat Dudek, PhD Bożena Karwat-Woźniak, \\ Institute of Agricultural and Food Economics \\ - National Research Institute, Warsaw, Poland \\ Michal.Dudek@ierigz.waw.pl,Bozena.Karwat-Wozniak@ierigz.waw.pl
}

DOI: $10.30858 / \mathrm{pw} / 9788376587431.18$

\begin{abstract}
Deagrarianisation constitutes one of the regularities of the economic development. This phenomenon is becoming increasingly apparent also in Poland and manifests itself in, for instance, the decline in the importance of the agricultural sector as a type of occupation. However, the Polish economy is still characterized by high agricultural employment, which determines the low labour productivity in this sector and results in its weak adaptation to the functioning in the conditions of competition. Further changes in agriculture are subject to the labour outflow to other sectors. This process is one of the objectives of the Polish labour market policy. The paper examines the scale of deagrarianisation of employment and its exogenous and endogenous conditions in the Polish economy. The effects of the support of labour outflow from the agriculture, which had been implemented through the Cohesion Policy as well as the RDP in the years between 2007 and 2015, were also assessed. According to the research results, the process of deagrarianisation of employment is continuous and sustainable. It was determined by many various factors, which can be divided into two groups: internal - pushing the labour force out of agricuture (supply), and external identifying the needs for employment outside agriculture (demand). As the analysis of ways and effects of the impact of projects financed from the EU funds on changes in agricultural labour resources proves that these initiatives contributed to the growth in non-agricultural employment, at different levels of effectiveness and sustainability of support depending on the type of allocation.
\end{abstract}

Keywords: deagrarianisation, employment, conditions of deagrarianisation, Cohesion Policy, RDP

JEL codes: J21, J23, J43

\subsection{Introduction}

Presently, the regularity of the economic development is the progressive deagrarianisation of the economies of individual countries [Timmer, 1988]. This phenomenon was increasingly observable also in Poland, and expressed itself in constantly decreasing number of people employed in agriculture. However, despite a clear downtrend trend, the Polish economy, compared to other European countries, 
was characterized by one of the highest employment rates in this sector ${ }^{44}$. A large number of people working in the domestic agriculture led to the adverse relations between the labour resources and the resources of land and capital. Consequently, this situation determined generally low work productivity [Baer-Nawrocka and Poczta, 2016]. As a result, the Polish agriculture was still poorly adapted to the functioning in the conditions of global competition [Ziętara, 2014], and further effectiveness-oriented changes of agricultural structures were determined by the pace of the agricultural labour outflow to other segments of the economy [Sikorska, 2013; Karwat-Woźniak, 2016]. The increase in employment in services and the limitation of hidden unemployment on farms had long been one of the objectives of the Polish labour market policy [Krajowa Strategia..., 2005; NSRO, 2007]. Together with the accession to the EU, the catalogue of public intervention tools aiming at supporting the implementation of this task has broadened ${ }^{45}$.

The aim of the paper was to analyse the current changes in the scale of agricultural employment in Poland, particularly in the family farming sector. The endogenous and exogenous conditions of deagrarianisation of labour were also outlined and the impact of the EU Cohesion Policy instruments and the agricultural and rural development policy (Rural Development Programme for 20072013, hereinafter RDP 2007-2013) on changes in the allocation of rural labour resources was determined. The paper uses the primary data gathered by the official statistics (GUS, Eurostat) as well as the results of panel surveys conducted by IERiGŻ-PIB (Institute of Agricultural and Food Economics-National Research Institute). The paper was supplemented by the analysis of secondary data including information on the implementation of national and regional operational programmes as well as RDP 2007-2013, studies commissioned by the government and self-government administration, as well as the relevant literature. The period covered by the observation concerned the period between 2007 and 2015 and partly earlier and later periods ${ }^{46}$.

\subsection{The conditions of the decrease in employment in agriculture}

The process of deagrarianisation, that is the decrease in the role of agriculture in the economy, is visible in many aspects: socio-economic, cultural, organic, manufacturing, legal and institutional [Roszkowski, 2009; Halamska, 2011; Wojewodzic, 2017]. Within the economic dimension, what is often analysed is

\footnotetext{
${ }^{44}$ According to the Eurostat, in 2016 the share of persons working in agriculture it total working population amounted to $10.6 \%$, while this rate for the EU-28 constituted $4.5 \%$. Higher employment rate in this sector was noted in Romania (24.0\%), Bulgaria (18.0\%) and Greece (11.3\%) was noted [European Commission, 2017 ].

${ }^{45}$ The data concerning agriculture involve also forestry, hunting and - since 2008 - fishing.

${ }^{46}$ This was done due to the fact that, within the frames of the financial perspective of 2007-2013, the projects supported from the EU funds were implemented in Poland in accordance with the $\mathrm{n}+2$ rule until the end of 2015 .
} 
the decrease in the significance of agriculture as a type of occupation on the macro-scale, which is referred to as the deagrarianisation of employment. The deagrarianisation of employment entails numeruous consequences and results or a number of reasons. Those factors can be generally divided into the exogenous, which are outside the agricultural sector, and endogenous, which relate to this area of economic activity (Figure 1). The first of the mentioned groups of determinants includes e.g.: the pace of economic growth, the level of entrepreneurship, the demand for work in the economy, demografic trends, legal and institutional issues.

Figure 1. The conditions of decrease in employment in agriculture

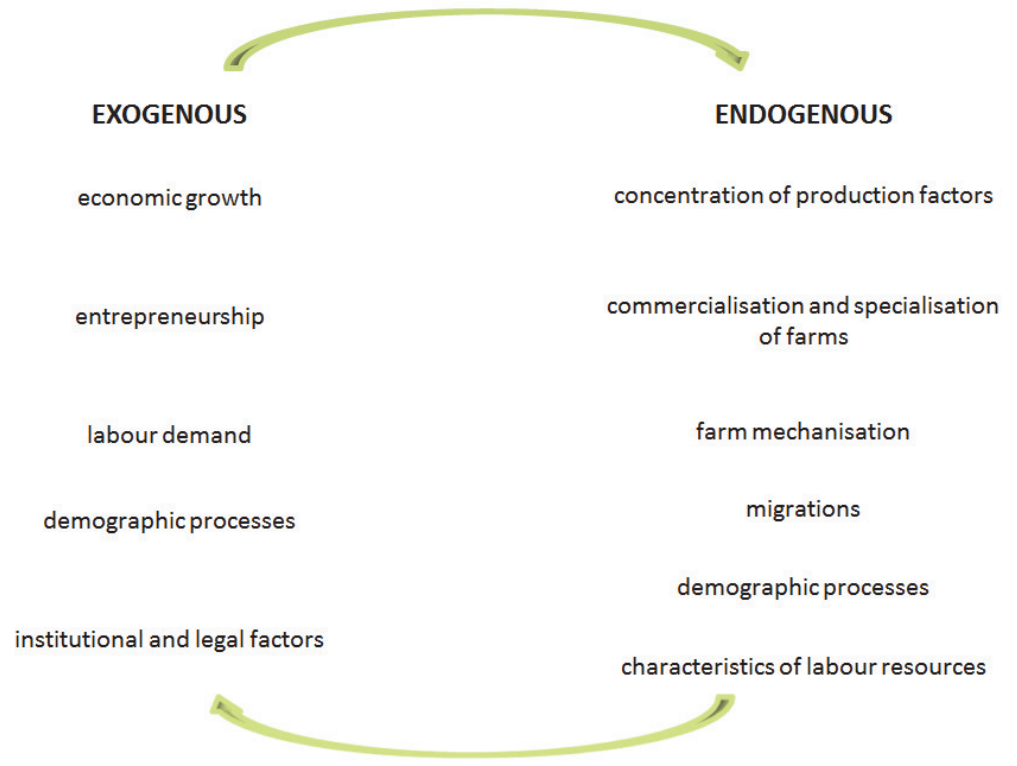

Source: own elaboration.

In modern economies, the force absorbing the labour recources from agriculture is the significant creation of value added and the employment in the service sector of the economy, which is accompanied by establishing and liquidating non-agricultural economic entities. At the same time, in the conditions of demografic ageing of populations, the competition on workers increases. As a result, those branches which offer better-paid jobs at better conditions are rewarded. The shape of legal and institutional solutions in the scope of social insurance, the taxation as well as the support of the professional activity affecting the working conditions in particular sectors of the ecoomy is also significant for the allocation of the labour force. 
Among the endogenous determinants affecting the proccess of deagrarianisation, the important issues are: the level of concentration of means of production, commercialization and specialization of farms as well as the mechanization of works. Those phenomena of various intensities are effects of the escalating competition among the agricultural producers, which generates the pressure to increase the effectiveness of production. It is connected to the declining demand for labour force, which is determined by social and demographic characteristics of the rural population and its tendency for the occupational mobility. Those numerous external and internal premises of deagrarianisation accumulate increasing the pace of this proccess or work in opposite directions (often neutralising their influence), which results in the further persistence of the significance of agriculture in employment.

\subsection{The change in the scale of employment in agriculture in Poland and its conditions}

In 2005-2016, the decrease in the significance of the acricultural sector in the employment of working people working in the Polish economy was observed. This proccess was expressed in both relative and absolute terms. The share of people working in agriculture in the analysed time interval decreased from $17.4 \%$ to $10.5 \%$ (Figure 2). The number of people working in this sector decreased, in turn, by $31 \%$. This changes resulted mainly from the decrease in the number of people working in the family farming, which decreased by ca. $33 \%$. Even though the scale of changes in the allocation of labour could be considered as significant, still it was one of the highest in Europe (twice as high as the average for all EU Member States and four times higher than in the so-called old Member States). In the analysed period, the role of agriculture as the area of occupational activity of rural population was also changing. Even though the rural inhibitants still dominate among those working in agriculture, they worked in this sector less frequently. In 2009-2016, the percentage of Polish rural inhabitants employed in agriculture decreased from $32 \%$ to less than $25 \%$.

The described changes in the scale of deagrarianisation of employment of the domestic economy were related to the favourable macroeconomic factors. The significant growth of the gross domestic product could be observed in Po$\operatorname{land}^{47}$. However, the dynamics of those changes in particular years varied. Nevertheless, in each analysed year, the real increases in GDP, expressed in both current prices (by at least $1.7 \%$ ) and in constant prices (by at least $1.4 \%$ ), was noted. The growth in production created the demand for work, especially in non-

\footnotetext{
${ }^{47}$ In 2016, in Poland, the level of GDP in the current prices amounted to 1.8 trillion and was over twice as high as in 2005. During this period, the GDP of current prices increased by almost $50 \%$, that is by $1.47 \%$ each year on average.
} 
-agricultural branches, both in respect to the urban and rural population. In the analysed time span, this phenomenon was reflected in the changes that were reported in the values of the employment and unemployment rates. Since 2005 to the third quarter of 2017 , the employment rate increased by $7 \%$ in the case of rural population and by $10 \%$ in the case of urban population. In consequence, the level of employment of the rural and urban inhabitants was similar and amounted to over $54 \%$. The unemployment rate, in turn, was decreasing and reached the same level for both urban and rural populations (5\%). At the same time, the increase in the number of job offers reported by enterpreneurs was observed. In the third quarter of 2017, this number amounted to almost 450 thousand and was over twice as high as in the corresponding period in 2012.

Figure 2. The people working* in the agricultural sector** and family farming in Poland in 2005-2016 (\%)

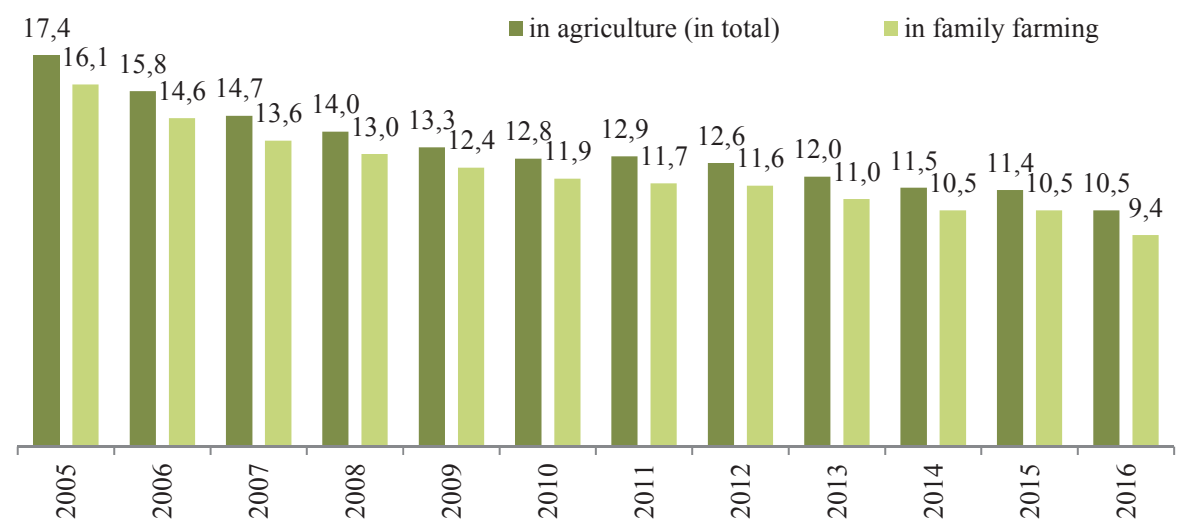

*Annual averages - arithmetic mean of quarterly data, the total of working people in Poland = 100. **Agriculture, hunting, fishery and fishing.

Source: based on GUS, LFS.

The decreased allocation of the labour factor in agriculture was also influenced by demographic determinants. The processes of population ageing were becoming visible in rural areas. These trends were accelerated, as evidenced by the increasing median age. In the case of urban inhabitants, it amounted to 41 years and increased within the last period (2010-2016) by ca. $5 \%$. The median age of rural inhabitants in 2016 amounted to 38 years and was higher by $6 \%$ compared to 2010. However, the rural population was still demographically younger than the urban population, which is also indicated by the structure of population according to the economic age groups. In 2016 , about $20 \%$ of the 
rural residents were people in pre-working age, and $17 \%$ - in the post-working age. In the case of the rural population, these proportions were reversed. The demographic forecasts developed by GUS showed that the aging process of the population will continue. The number of people in the post-working age will increase. In 2040, the share of this group will constitute over $25 \%$. The group of people in the pre-working age will decrease, which means that smaller number of people will enter the labour market. The ageing of the population will also create new vacancies, e.g. for nursing services.

Among the endogenous factors of deagrarianisation of employment in the economy, relatively dynamic concentration processes, especially of the agricultural land, should be emphasized. The majority of the resources of agricultural land were in the group of large farms (over 50 ha of UAA) and amounted to $32 \%$ of the total. However, still relatively large part of land was owned by small agricultural holdings, which - due to their small area - are considered as nondeveloping (about 13\% of land was used by farms with the area of up to 5 ha, which constituted more than a half of all farms in Poland). When it comes to the EU Member States, with which - due to the structure of agricultural commercial production - the Polish agriculture competes, the share of agricultural land owned by the farms with the area of 50 ha and higher amounted to $80-90 \%$. Together with the concentration proccesses of land, the investment expenditures on the fixed assets in agriculture were increasing. In 2015 this expenditures in constant prices were higher by $50 \%$ compared to 2010 , and by $80 \%$ compared to 2005. On average, approximately one third in those investments were aimed at the mechanization of works, which led to the growth of the capital-labour ratio. From the point of view of the demand for labour force, the comprehensive mechanisation of all phases of the production process is important. Based on surveys conducted by IERiGŻ-PIB, the scale of comprehensive mechanisation was assessed. The number of farms with complex mechanisation increased up to $20 \%$. This process was visible particularly in the group of commercial farms, regardless of the production profile.

\subsection{The instruments of the Cohesion Policy and agriculture and rural development of the EU policy and employment deagrarianisation in Poland}

In 2007-2015, the Cohesion Policy and the agriculture and rural development policy contributed to the deagrarianisation of employment in the Polish economy. It should be noted that both types of public intervention that were mentioned had directly or indirectly articulated aim in the form of decreasing the role of this sector as a place of employment, and the scale of financial resources 
engaged in their implementation was relatively significant ${ }^{48}$. The activities oriented at the increase in the non-agricultural occupational activity were an important element of the EU policy appointed by the Lisbon Strategy and CAP's objectives. They concerned the creation of a competitive and knowledge-based economy, providing jobs as well as the economic, social and spatial cohesion.

The shape of domestic systems of implementation of the Cohesion Policy and the agricultural and rural development policy were the reflection of the assumptions and rules of the support shaped at the EU level. The Cohesion Policy financed by the European Regional Development Fund (ERDF), the Cohesion Fund (CF) and the European Social Fund (ESF) were implemented in Poland primarily through five nationwide programmes (Operational Programme: Infrastructure and Environment - OP I\&E, Innovative Economy - OP IE, Human Capital - OP HC, Development of Eastern Poland - OP DEP, Technical Assisstance - OP TA, which covered $74 \%$ of the financial funds allocated to Poland by the EU) as well as sixteen regional operational programmes (ROPs, $25 \%$ of

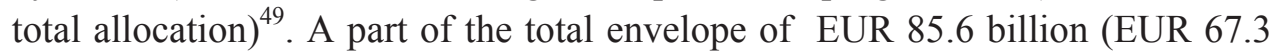
billion came from the EU budget, EUR 11.9 billion from national public funds, and EUR 6.4 billion from private sector) were allocated for the projects related, among others, to the promotion of entrepreneurship, trainings, occupational extension and retraining. These actions had to contribute to the equalization of opportunities for development and supporting the structural changes in the countryside, as well as to the growth of its non-agricultural functions. The diversification and development of the rural economy in the direction of non-agricultural functions and the employment promotion among rural residents in Poland were also supported by the CAP funds coming from the European Agricultural Fund for Rural Development (EAFRD), provided for the implementation of RDP 2007-2013 [Regulation No. 1698/2005 2005, RDP 2007-2013]. The total budget of this programme in the country amounted to over EUR 25 billion, and it was planned that less than EUR 3 billion of this sum (that is 12\% of the total budget of the Programme) would be allocated to instruments directly aimed at increasing of the non-agricultural employment and entrepreneurship ${ }^{50}$. These funds were available mainly as part of the RDP 2007-2013 measures of the third and

\footnotetext{
${ }^{48}$ It is estimated that, within the entire programming period, PLN 109 billion were allocated to the interventions undertaken within the framework of structural funds and the $\mathrm{CF}$, the purpose of which was to generate the employment effects. This money constituted $44 \%$ of the EU total allocation in projects [Wpływ realizacji..., 2016]. For the implementation of the RDP 2007-2013 PLN 4.3 billion (i.e. about $6 \%$ of total public budget of the RDP) were allocated to the projects linked with the support and promotion of non-agricultural occupational activity of rural population.

${ }_{49} 1 \%$ of all EU funds allocated to Poland in the programming period from 2007 to 2013 were devoted for the financing of the European Territorial Cooperation Programmes.

${ }^{50}$ Due to the problems in implementing the measure no. 312 of the RDP 2007-2013, the final allocation was almost halved [Ocena wpływu..., 2016].
} 
fourth axes, i.e. Diversification into non-agricultural activity, The establishment and development of micro-enterprises and The Implementation of the Local Development Strategies (measures no. 311, 312 and 413).

Both in relation to the Cohesion Policy and the RDP 2007-2015, the impact of public intervention on the deagrarianisation of employment in Poland was indirect (the overall impact of programmes on the demand for work of non-agricultural entities) and direct (effects of instruments strictly focused on supporting workers' moving away from agriculture and establishing new jobs outside this sector). In the case of the Cohesion Policy, in the entire programming period, the total number of jobs created as a result of this policy was estimated at 173-282 thousand of jobs, which translated into about 190 thousand jobs expressed in full-time equivalent. This growth was mainly determined by ROPs, but also by the OP IE and the OP HC ${ }^{51}$ [Wpływ realizacji..., 2016]. It is estimated that, out of the total number of jobs established as a result of the intervention of European funds, approximately 30\% were created in rural areas and in towns of up to 5 thousand inhabitants [Wpływ realizacji..., 2016]. New jobs were created mostly in the construction and in services sectors, as well as - but to a lesser extent - in the industry. It is worth noting that the Cohesion Policy's intervention in Poland did not contribute to the growth of the employment in agriculture, what proves its clear deagrarianisation effect (Table 1). However, it should be mentioned that a relatively high proportion of new jobs was created strictly to implement the EU-funded projects [Wpływ realizacji..., 2016].

Within the Cohesion Policy, the projects directly related to the increase of rural, non-agricultural employment were implemented by the instruments of the ESF funds as a part of OP HC, OP DEP and ROP (self-employment, promoting employment, entrepreneurship, business creation) $)^{52}$. One of such forms of the improvement in the case of employment and in the labour market was the support for setting up a business available in the OP HC [Badanie skuteczności..., 2013]. This support allowed to establish 247.7 thousand businesses [Sprawozdanie końcowe..., 2017]. It is estimated that about 99.7 thousand of these companies were established in rural areas [Badanie skuteczności..., 2013, Sprawozdanie końcowe..., 2017].

\footnotetext{
${ }^{51}$ The majority of full-time jobs' equivalents were established at the beneficiaries as a result of implementation of the ROP (98 thousand). In this regard, a smaller contribution was noted for OP IE (around 52 thousand of EPC) and OP HC (around 35 thousand of the EPC). Relatively small impact in the case of the OP DEP (4 thousand) was observed.

${ }_{52}$ In the entire programming period, 583.6 thousad of rural residents participated in the projects aimed at the employment growth within the framework of the OP HC Priority VI Labour Market Open to Everyone. Six months after the completion of the participation in these projects, $76 \%$ of the participants from these areas were employed [Sprawozdanie końcowe..., 2017].
} 
Table 1. Selected programmes as well as instruments of the EU Cohesion Policy and CAP supporting the deagrarianisation of employment in Poland, 2007-2015

\begin{tabular}{|l|c|c|}
\hline \multicolumn{1}{|c|}{ Details } & $\begin{array}{c}\text { the number of created jobs } \\
\text { (thousands) }\end{array}$ & $\begin{array}{c}\text { impact on agricultural } \\
\text { employment }\end{array}$ \\
\hline OP HC $^{* *}$ & 34.5 & - \\
\hline OP DEP & 4.1 & - \\
\hline OP I\&E & 5.2 & - \\
\hline OP IE & 51.7 & - \\
\hline ROP & 97.5 & $+/-$ \\
\hline Measure 311 of RDP 2007-2013 & 13.8 & + \\
\hline Measure 312 of RDP 2007-2013 & 24.0 & $+/-$ \\
\hline Measure 413 of RDP 2007-2013 & 1.9 & of jobs \\
\hline
\end{tabular}

* In the case of the programmes financed by the ERDF and the ESF, the number of jobs was expressed as the equivalent of full-time jobs. The estimates did not include the effects of the OP TA. ${ }^{* *}$ In addition, it is estimated that as a result of the support offered within the OP HC Priority VI concerning starting up a business, 250 thousand new jobs were created.

Source: own elaboration based on [Sprawozdanie... 2015, Wplyw realizacji... 2016, Sprawozdanie końcowe... 2017].

Regarding the overall impact of the RDP 2007-2013 on employment, within the entire programming period, the average annual increase of 41 thousand jobs was reported. In absolute terms, it covered all sectors of the economy [Zaleski, 2015]. The impact of the Programme on the increase in the share in the structure of employees working in the services sector and construction sector was noted, which, at the same time, translated in this respect into a relative decline in the importance of agriculture. However, it should be assumed that the overall deagrarianisation effect of the RDP 2007-2013 was limited by direct payments and other support provided within CAP, which may have caused a part of the rural population to remain in the sector [Olper et al., 2014].

The RDP measures, directly supporting the increase in the non-agricultural employment, in the entire programming period, contributed to the creation of 37.9 thousand of new jobs. In this respect, the relatively largest effects were associated with poviding the support in order to run or develop a non-agricultural business (Measure 312). Thanks to the received subsidy, over 14.5 thousand projects were covered by the support (funds were mostly allocated to rural businesses established before founding), as a result of which 24 thousand non-agricultural jobs were created [Sprawozdanie..., 2015]. These were mainly jobs related to the provision of services (construction and installation, agricultural, tourism, recreation and sports services). Low effectiveness and sustainability of the support, as well as the limited impact on non-agricultural employment characterised, in turn, the Programme measures associated with the diversifica- 
tion of agricultural activity ${ }^{53}$ and the implementation of the Local Development Strategies $^{54}$ (Measures 311 and 413). The financial support was usually used for development of traditional forms of farming activity, which was not conducive to outflow of employees from agriculture [Ocena wpływu..., 2016].

\subsection{Summary and conclusions}

In 2005-2016 the process of deagrarianisation of employment in the Polish economy was observed. The employment rate in domestic agriculture decreased from 17.5 to $10.5 \%$. As a consequence, the level of agricultural employment observed in Poland reached the maximum value which is considered for highly developed economies. It should be noted that exogenous factors associated with the increase in the global production and the increase in the demand for jobs in non-agricultural sectors were of essential significance for this process. The favourable economic situation was accompanied by demographic and social trends that contributed to shrinking of the agricultural labour resources. At the same time, determinants inherent in this sector turned out to be significant for the outflow of employees. In particular, they concerned gradual concentration of agricultural land, improvement of the level and complexity of production mechanization, as well as the increase in the production specialization. These changes resulted in a decrease in the demand for labour force, mainly in family farms.

Instruments of the EU Cohesion Policy and the CAP contributed to the increase in non-agricultural employment of rural population. In 2007-2015 in Poland, according to various estimates, the number of 213-495 thousand of new non-agricultural jobs were created thanks to these interventions. These numbers could be supplemented by 250 thousand jobs resulting from the actions supporting the sturt-ups' creation. However, it should be taken into account that the results, effectiveness and sustainability of individual projects varied depending on the subject of allocation. Many of the induced employment effects were expensive, unsustainable and unnecessarily involving public funds. It should be expected that the deagrarianisation trends in Poland, which are decribed in the text, will persist in the coming years. Regardless of the significance of the instruments of public policy aimed at increasing non-agricultural employment in the

\footnotetext{
${ }^{53}$ As a part of diversification into non-agricultural activity, 15.3 thousand people received support and they implemented 15.7 thousand projects. They were allocated to the activity consisting in offering services for agricultural holdings and forestry (10.9 thousand projects, which constituted $70 \%$ of all operations under the Measure 311). The research carried out among the beneficiaries indicated that 13.8 thousand jobs outside agriculture were created thanks to the received subsidies, 11.9 thousand of which were of permanent full-time positions [Sprawozdanie..., 2015].

${ }^{54}$ Within the LEADER approach, 1.8 thousand people associated with farms and running additional economic activity (in more than a half of the cases in the form of services for agriculture and forestry) and 1.4 thousand projects undertaken by the new and existing non-agricultural economic entities were supported. With the support of the EAFRD, 1938 new jobs were created [Sprawozdanie..., 2015].
} 
future, the pace of the economic development and the scale of demand for labour created by services sector will be crucial for the continuation of the structural changes in the Polish agriculture. In coming years, the latter should be stimulated mainly by demographic trends, particularly population aging.

\section{References}

1. Halamska, M. (2011). Transformacja wsi 1989-2009: zmienny rytm modernizacji. Studia Regionalne i Lokalne, (2/44), 5-25.

2. Baer-Nawrocka, A., Poczta, W. (2016), Polskie rolnictwo na tle rolnictwa Unii Europejskiej. [In:] Wilkin, J., Nurzyńska, I., (eds.), Rural Poland 2016. Rural Development Report, Fundation for the Developmentof Polish Agriculture, Wydawnictwo Naukowe SCHOLAR, Warsaw, 81-106.

3. Karwat-Woźniak, B. (2016). Structural Conditions of the Competitiveness of Polish Agriculture. Marketing i Rynek no. 10, 230-245.

4. European Commission, (2017). CAP Context Indicators 2014-2020, https://ec.europa.eu/agriculture/cap-indicators/context_pl (access: 1 February 2018).

5. Krajowa Strategia Zatrudnienia na lata 2007-2013, (2005). Ministry of Economy and Labour, Warsaw.

6. Sprawozdanie z realizacji Programu Rozwoju Obszarów Wiejskich na lata 2007-2013, (2015), no. 9/2015, Ministry of Economy and Labour, Warsaw.

7. Narodowe Strategiczne Ramy Odniesienia 2007-2013 wspierające wzrost gospodarczy i zatrudnienie. Narodowa Strategia Spójności, (2007). Ministry Of Regional Development, Warsaw.

8. Ocena wpływu PROW 2007-2013 na jakość życia na obszarach wiejskich $\mathrm{z}$ uwzględnieniem podejścia LEADER, (2016). EGO, Final report, Ministry of Agriculture and Rural Development, Warsaw, 64-84.

9. Olper, A., Raimondi, V., Cavicchioli, D., Vigani, M., (2014). Do CAP payments reduce farm labour migration? A panel data analysis across EU regions, European Review of Agricultural Economics, vol. 41(5), 843-873.

10. RDP 2007-2013, (2007). Ministry of Agriculture and Rural Development, Warsaw. 11.RDP 2007-2013, (2016). Ministry of Agriculture and Rural Development, Warsaw.

12. Sikorska, A. (2013). Land Turnover and Agrarian Changes in Individual Farming, Zagadnienia Ekonomiki Rolnej no. 1/334, Institute of Agricultural and Food Economics National Research Institute, Warsaw.

13. Sprawozdanie końcowe z wdrażania Programu Operacyjnego Kapitał Ludzki 2007-2013, (2017). Ministry of Development, Warsaw

14. Roszkowski, A., (2009). Odchodzenie wsi od rolnictwa a inżynieria rolnicza, Problemy Inżynierii Rolniczej 1 (63), 23-33.

15.Timmer, C.P. (1988). The agricultural transformation. Handbook of Development Economics, 1, 275-331.

16. Wojewodzic, T. (2017). Procesy dywestycji i dezagraryzacji w rolnictwie o rozdrobnionej strukturze agrarnej, Zeszyty Naukowe UR im. Hugona Kołłątaja w Krakowie, Cracow, 218-219. 
17. Wpływ realizacji NSRO 2007-2013 na poziom i jakość zatrudnienia w Polsce. Raport końcowy. (2016). WYG PSDB Sp. z o.o. and Evalu Sp. z o.o., Ministry of Development, Warsaw, 47-49, 78, 85.

18.Zaleski, J. (2015), Ocena wpływu Programu Rozwoju Obszarów Wiejskich 20072013 na gospodarkę Polski. Raport końcowy, Wrocław Regional Development Agency S.A., Wroclaw.

19.Ziętara W. (2014), The Competitive Position of Polish Agricultural Holdings as Against Their Equivalents in Selected European Countries, Problemy Drobnych Gospodarstw Rolnych 4, 63-78. 